\title{
Post Harvest Losses, Marketing Pattern and Constraints of Chick pea in Northern Hills of Chhattisgarh
}

\author{
Mukesh Kumar Seth ${ }^{1 *}$, Meghraj Chandrakar ${ }^{1}$ and Ajay Kumar Gauraha ${ }^{2}$ \\ ${ }^{1}$ Department of Agricultural Economics, Indira Gandhi Krishi Vishwavidalya, Raipur, Chhattisgarh, India \\ ${ }^{2}$ Department of Agri-Business and Rural Management, College of Agriculture, IGKV, Raipur, Chhattisgarh, India \\ *Corresponding author: mukeshseth.seth1@gmail.com
}

\begin{abstract}
The study to examine the post harvest losses and marketing pattern of chick pea has been done in Jaspur district of Northern hills of Chhattisgarh state. The study was undertaken by taking 60 sample farms during the year 2016-17. Formal survey method was used to collect required information from sample area. The objectives were achieved by using exponential function, regression and perception analyses. The overall post harvest loses at farm level was estimated to be $6.06 \mathrm{~kg} /$ quintal and $38.21 \mathrm{~kg} / \mathrm{hectare}$ and maximum losses found during drying (36.93\%) followed by storage (35.61\%) and harvesting of chick pea $(09.81 \%)$ to the total losses. Total post-harvest losses at farms level was found to be the maximum in large farms being $7.02 \mathrm{~kg}$. The marketable surplus in chick pea at marginal, small, medium, large and overall farms were 1.81, 2.62, 4.43, 18.27 and 4.17 quintal per farm constituting 67.79, 70.37, 73.46, 77.87 and 71.41 per cent to their total production respectively. The overall quantity of chick pea sold by producer was 2.07 (49.65\%), $1.19(28.47 \%)$ and 0.91 (21.88\%) direct to consumer, village trader and wholesaler respectively. In post harvest losses unavailability of capital (80\%) ranks first among all constraints and in marketing of chick pea lack of cheap transportation facility (95\%) was the major constraint. It is suggested that there is a need to smoothening the process of farmer credit by financial agencies in the study area for minimizing post harvest losses. Also availability of cheap transportation facility will help to strengthen the marketing channel of the study area.
\end{abstract}

Keywords: Chick pea, post-harvest losses, pulses, marketing pattern, marketing channel, constraint

Pulses constitute an essential part of the Indian diet for nutritional security and environmental sustainability. The protein content of pulses viz., chickpea $(18-22 \%)$, pigeonpea $(21.7 \%)$, mung or green gram (23-24\%), and urd or black gram (25$26 \%$ ) make good position in term of health and economic in India. Besides, protein content, pulses has a well balanced profile of essential amino acids. The country produces a variety of pulses including chickpea (40 per cent). According to a World Bank (1999) study post-harvest losses of food grains in India are 7-10 per cent of the total production from farm to market level and 4-5 per cent at market and distribution level. According to the World Bank "Missing Food" report of 2011, loss is estimated to be 7-10 per cent at the farm to market level and another 4-5 per cent at market and distribution level.
The present study is an attempt to examine the post harvest losses and marketing pattern of chick pea in northern hills in Chhattisgarh and to identify the constraints in the post harvest management and marketing of chick pea in study area thereby increasing production and profitability of farmers in present scenario.

\section{METHODOLOGY}

The study was finite to Jaspur district of Chhattisgarh state. Out of 6 blocks, Patthalgaon and Pharsabahar blocks of Jaspur district were selected on the basis of inducting maximum area among all pulses crops of chickpea in rabi season. The list of chick pea grower villages was obtained from the office of Deputy Director of Agriculture, Jaspur for the year 2016-17. From the list of chick pea grower villages, 2 villages 
from each block and 25 per cent (i.e. at least 15 chick pea growers from each village) chick pea growers were considered for the study. There were 60 chick pea growers, which comprised of 17, 20, 17, and 6 (Table 1) chick pea growers of marginal, small, medium and large size categories, respectively. The primary data were collected from sample farmers on all the relevant aspects by using well structured schedule to fulfill the objectives of study. The simple averages and percentages were applied to analyze the data and report the results as per the objectives framed for study.

Table 1: General information of households in Northern Hills of Chhattisgarh

\begin{tabular}{ccccc}
\hline $\begin{array}{c}\text { Farm } \\
\text { Size }\end{array}$ & $\begin{array}{c}\text { No. of } \\
\text { Sample } \\
\text { farms }\end{array}$ & $\begin{array}{c}\text { Average } \\
\text { farm size } \\
\text { (ha.) }\end{array}$ & $\begin{array}{c}\text { Area } \\
\text { under } \\
\text { chick pea } \\
\text { (ha.) }\end{array}$ & $\begin{array}{c}\text { Cultivated } \\
\text { area (\%) }\end{array}$ \\
\hline Marginal & 17 & 0.63 & 0.45 & 71.43 \\
Small & 20 & 1.47 & 0.6 & 40.82 \\
Medium & 17 & 2.37 & 0.93 & 39.24 \\
Large & 6 & 5.65 & 3.37 & 59.65 \\
\hline Total & $\mathbf{6 0}$ & $\mathbf{1 . 9 1}$ & $\mathbf{0 . 9 3}$ & $\mathbf{4 8 . 6 9}$ \\
\hline
\end{tabular}

\section{Factors affecting post-harvest losses at farm level}

Functional analysis was carried out to examine the factors affecting post-harvest losses at farm level in chickpea, as used by Nag et al. (2000) in chickpea. The following multiple linear regression function was specified in the present study:

$$
\begin{gathered}
Y=a_{0}+a_{1} X_{1}+a_{2} X_{2}+a_{3} X_{3}+a_{4} X_{4}+a_{5} X_{5}+a_{6} X_{6}+ \\
a_{7} X_{7}+a_{8} X_{8}+e
\end{gathered}
$$

Where,

$\mathrm{Y}=$ Post-harvest losses of chick pea at farm level in quintals per ha

$\mathrm{X}_{1}=$ Education of the respondents in years

$\mathrm{X}_{2}=$ Total production of chick pea in quintals

$\mathrm{X}_{3}=$ Area under chick pea (ha)

$\mathrm{X}_{4}=$ Area under irrigation (ha)

$X_{5}=$ Storage losses which takes the value in percentage.

$X_{6}=$ Weather losses which takes the value in percentage.

$X_{7}=$ Transportation losses which takes the value in percentage.
$\mathrm{X}_{8}=$ Threshing machine losses which takes the value in percentage.

$\mathrm{e}=$ Random-error

\section{Marketable surplus}

$$
\mathrm{MS}=\mathrm{P}-(\mathrm{C}+\mathrm{W})
$$

Where,

MS = Marketable Surplus

$\mathrm{P}=$ Total Production

$\mathrm{C}=$ Family Consumption

$\mathrm{W}=$ Quantity use for Wage

\section{Constraints in post harvest management and marketing of chick pea}

Constraints in production and marketing of chick pea in the sampled farms were analyzed and examined using perception and experience of the chick pea growing farmer.

\section{RESULTS AND DISCUSSION}

\section{Post-harvest losses}

The estimated total post-harvest losses per quintal of chick pea produced or handled at different stages are presented in Table 3. The overall loss was to be $6.06 \mathrm{~kg} / \mathrm{q}$ in chick pea at the farm level. Losses in $\mathrm{kg} /$ hectare were also work out which was found to be $38.21 \mathrm{~kg} / \mathrm{ha}$. Losses were found to be maximum in drying of chick pea (36.93\%) followed by storage $(35.61 \%)$ and harvesting $(09.81 \%)$ to the total losses in chick pea. Total post harvest losses at farms level was found to be the maximum in large farms being $7.02 \mathrm{~kg}$ and shows an increasing trend from marginal to large farms.

\section{Factor affecting post-harvest losses}

The factors affecting post harvest losses at farm level were presented in Table 2. The table reveals that the weather dummy found positively correlate $(p>0.01)$ and education of farmers are found to be negatively correlate $(p>0.05)$. The total production, age of respondent and area under irrigation dummy, storage dummy, threshing dummy, transportation dummy variables were found to be positive but non-significant and all other dummy variable were negative and were non-significant to the post harvest at farm level. 
Table 2: Factors affecting post-harvest losses in chick pea at farm level in Northern Hills

\begin{tabular}{cccc}
\hline S1. No. & Explanatory variables & Coefficients & P-value \\
\hline 1 & Intercept & 5.391919 & $4.16 \mathrm{E}-06$ \\
2 & Age of respondent & 0.00572 & 0.536761 \\
3 & Education & $-0.01526^{*}$ & 0.047577 \\
4 & Total Production & -0.00053 & 0.703162 \\
5 & Area & -0.09885 & 0.611693 \\
6 & Area under Irrigation & 0.214105 & 0.205283 \\
7 & Storage Dummy & 0.193392 & 0.371698 \\
8 & Weather Dummy & $1.2098^{* *}$ & 0.000341 \\
9 & Transportation Dummy & 0.149328 & 0.533955 \\
10 & Threshing Dummy & 0.357614 & 0.281475 \\
11 & Timely Labour availability dummy & -0.0453 & 0.852303 \\
12 & Multiple R & 0.841668 & \\
13 & R Square & 0.708404 & \\
14 & Adjusted R Square & 0.648895 & \\
\hline
\end{tabular}

${ }^{* *}$ Level of significance $p<0.01 ; *$ Level of significance $p<0.05$

Table 3: Post harvest losses in chick pea in Northern Hills of Chhattisgarh state

\begin{tabular}{|c|c|c|c|c|c|c|c|c|c|c|c|}
\hline \multirow[b]{2}{*}{$\begin{array}{l}\text { Sl. } \\
\text { No. }\end{array}$} & \multirow[b]{2}{*}{ STAGE } & \multicolumn{2}{|c|}{ MARGINAL } & \multicolumn{2}{|c|}{ SMALL } & \multicolumn{2}{|c|}{ MEDIUM } & \multicolumn{2}{|c|}{ LARGE } & \multicolumn{2}{|c|}{ OVERALL } \\
\hline & & $\begin{array}{c}\text { Loss } \\
\text { (per ha.) }\end{array}$ & $\begin{array}{l}\text { Losses } \\
\text { (Kg. per } \\
\text { quintal) }\end{array}$ & $\begin{array}{c}\text { Loss } \\
\text { (per ha.) }\end{array}$ & $\begin{array}{c}\text { Loss (per } \\
\text { qt.) }\end{array}$ & $\begin{array}{c}\text { Loss (per } \\
\text { ha.) }\end{array}$ & $\begin{array}{l}\text { Loss } \\
\text { (per qt.) }\end{array}$ & $\begin{array}{c}\text { Loss } \\
\text { (per ha.) }\end{array}$ & $\begin{array}{c}\text { Loss (per } \\
\text { qt.) }\end{array}$ & $\begin{array}{c}\text { Loss } \\
\text { (per ha.) }\end{array}$ & $\begin{array}{c}\text { Loss (per } \\
\text { qt.) }\end{array}$ \\
\hline 1 & Harvesting & 3.20 & $\begin{array}{c}0.54 \\
(09.78)\end{array}$ & 3.56 & $\begin{array}{c}0.57 \\
(09.79)\end{array}$ & 4.06 & $\begin{array}{c}0.63 \\
(09.66)\end{array}$ & 5.05 & $\begin{array}{c}0.73 \\
(10.33)\end{array}$ & 3.75 & $\begin{array}{c}0.59 \\
(09.81)\end{array}$ \\
\hline 2 & Transportation & 1.30 & $\begin{array}{c}0.22 \\
(03.99)\end{array}$ & 1.43 & $\begin{array}{c}0.23 \\
(03.92)\end{array}$ & 1.67 & $\begin{array}{c}0.26 \\
(03.96)\end{array}$ & 1.68 & $\begin{array}{c}0.241 \\
(03.43)\end{array}$ & 1.49 & $\begin{array}{c}0.24 \\
(03.89)\end{array}$ \\
\hline 3 & Threshing & 3.08 & $\begin{array}{c}0.52 \\
(09.42)\end{array}$ & 3.04 & $\begin{array}{c}0.49 \\
(08.36)\end{array}$ & 4.37 & $\begin{array}{c}0.67 \\
(10.39)\end{array}$ & 5.04 & $\begin{array}{c}0.72 \\
(10.31)\end{array}$ & 3.63 & $\begin{array}{c}0.57 \\
(09.47)\end{array}$ \\
\hline 4 & Winnowing & 0.89 & $\begin{array}{c}0.15 \\
(02.72)\end{array}$ & 1.49 & $\begin{array}{c}0.24 \\
(04.09)\end{array}$ & 2.06 & $\begin{array}{c}0.32 \\
(04.90)\end{array}$ & 3.27 & $\begin{array}{c}0.47 \\
(06.70)\end{array}$ & 1.66 & $\begin{array}{c}0.26 \\
(04.28)\end{array}$ \\
\hline 5 & Drying & 12.69 & $\begin{array}{c}2.14 \\
(38.77)\end{array}$ & 13.72 & $\begin{array}{c}2.21 \\
(37.69)\end{array}$ & 14.87 & $\begin{array}{c}2.29 \\
(35.35)\end{array}$ & 17.05 & $\begin{array}{c}2.45 \\
(34.90)\end{array}$ & 14.09 & $\begin{array}{c}2.24 \\
(36.93)\end{array}$ \\
\hline 6 & Storage & 11.56 & $\begin{array}{c}1.95 \\
(35.33)\end{array}$ & 13.17 & $\begin{array}{c}2.12 \\
(36.15)\end{array}$ & 15.03 & $\begin{array}{c}2.32 \\
(35.75) \\
\end{array}$ & 16.77 & $\begin{array}{c}2.41 \\
(34.33)\end{array}$ & 13.60 & $\begin{array}{c}2.16 \\
(35.61)\end{array}$ \\
\hline & Total & 32.73 & $\begin{array}{l}5.52 \\
(100)\end{array}$ & 36.42 & $\begin{array}{l}5.86 \\
(100)\end{array}$ & 42.06 & $\begin{array}{l}6.49 \\
(100)\end{array}$ & 48.86 & $\begin{array}{c}7.02 \\
(100)\end{array}$ & 38.21 & $\begin{array}{c}6.06 \\
(100)\end{array}$ \\
\hline
\end{tabular}

Note: Figure in the parenthesis indicates percentage to the total post-harvest losses in their respectively category.

\section{Marketing pattern}

In Jaspur district there are following two widely used marketing channels for marketing of chick pea were identified.

- Channel - I: Pulses growers' $\rightarrow$ Consumer (village market)
- Channel - II: Pulses growers' $\rightarrow$ Retailer $\rightarrow$ Consumer.

\section{Marketable surplus}

In chick pea, total obtained farm produce was as $2.67,3.37,6.03,23.46$ and 5.84 quintal per farm 
for marginal, small, medium, large and overall farms respectively. The marketable surplus in chick pea was 1.81, 2.62, 4.43, 18.27 and $4.17 \mathrm{q} /$ farm constituting 67.79, 70.37, 73.46, 77.87 and 71.41 percent to their total production (Table 4) for marginal, small, medium, large and overall farms respectively. The total quantity utilized by farmer for their different aspects were decreasing with increasing of farm size at sampled farms.

\section{Disposable pattern}

From total marketable surplus the quantity of chick pea sold by producer to different marketing functionaries of the sample household has been worked out in Table 5. The quantity of chick pea sold through consumer was 61.94 per cent (1.12 qt/ farm), 53.09 per cent (1.39 qt/farm), 43.07 per cent (1.91 qt/farm), 31.00 per cent (5.66 qt/farm) and 49.65 per cent $(2.07 \mathrm{qt} /$ farm $)$ of marginal, small, medium, large and overall farm, respectively. The quantity sold through village trader was 23.38 per cent $(0.42$ qt/farm), 30.89 per cent (0.81 qt/farm), 27.94 per cent $(1.24 \mathrm{qt} /$ farm $), 33.95$ per cent $(6.20 \mathrm{qt} /$ farm $)$ and 28.47 per cent (1.19 qt/farm) of marginal, small, medium, large and overall farm, respectively. The quantity of pigeon pea sold through wholesaler was 14.68 per cent $(0.26 \mathrm{qt} / \mathrm{farm}), 16.02$ per cent (0.42 qt/ farm), 28.99 per cent (1.28 qt/farm), 35.06 per cent $(6.40 \mathrm{qt} / \mathrm{farm})$ and 21.88 per cent $(0.91 \mathrm{qt} /$ farm $)$ of marginal, small, medium, large and overall farm, respectively. It may be noted, that the pigeon pea growers were left with relatively small marketable surplus to dispose-off the produce.

\section{Constraints in post harvest management of chick pea}

The experience of farmer about constraints which were faced during handling of post harvest management of chick pea has been presented in Table 6. Mainly eight major constraints were found to be responsible for the mismanagement of post harvest operations. Non-availability of capital (80\%) has first rank was found to be the major constraint followed by non-availability of good transportation facility and non- availability of labour being 73.33 and 70 percentages respectively.

\section{Farmer perceptions in Constraint in marketing of major pulses}

The major constraints pertaining to marketing of chick pea present in Table 7, the table reveals that Among the all Lack of cheap transportation was the most important problem as reported by 95 per cent chick pea growers. The second most

Table 4: Marketable surplus of chick pea in Northern Hills of Chhattisgarh state. (Q / farm)

\begin{tabular}{|c|c|c|c|c|c|c|}
\hline \multirow{2}{*}{ S1. No. } & \multirow{2}{*}{ Particulars } & \multicolumn{4}{|c|}{ Size groups } & \multirow{2}{*}{ Overall } \\
\hline & & Marginal & Small & Medium & Large & \\
\hline 1 & Total quantity produce & $2.67(100)$ & $3.37(100)$ & $6.03(100)$ & $23.46(100)$ & $5.84(100)$ \\
\hline 3 & Consumption and others & $0.72(27.15)$ & $0.89(23.99)$ & $1.27(21.14)$ & $3.91(16.67)$ & $1.36(23.19)$ \\
\hline 4 & Total quantity utilized & $0.86(32.21)$ & $1.10(29.63)$ & $1.60(22.13)$ & $5.19(22.13)$ & $1.67(28.59)$ \\
\hline
\end{tabular}

Note: Figure in parenthesis indicates percentage to the total production at farm level.

Table 5: Quantity of chick pea sold by producer to different marketing functionaries of the sample households (Northern Hills) (Q/Farm)

\begin{tabular}{cccccc}
\hline Sl. No. & Farm size & Consumer & Village trader & Wholesaler & Total \\
\hline 1 & Marginal & $1.12(61.94)$ & $0.42(23.38)$ & $0.26(14.68)$ & $1.80(100)$ \\
2 & Small & $1.39(53.09)$ & $0.81(30.89)$ & $0.42(16.02)$ & $2.62(100)$ \\
3 & Medium & $1.91(43.07)$ & $1.24(27.94)$ & $1.28(28.99)$ & $4.43(100)$ \\
4 & Large & $5.66(31.00)$ & $6.20(33.95)$ & $6.40(35.06)$ & $18.27(100)$ \\
5 & Overall & $2.07(49.65)$ & $1.19(28.47)$ & $0.91(21.88)$ & $4.17(100)$ \\
\hline
\end{tabular}

Note: Figure in parenthesis to the total marketable surplus. 
Table 6: Constraints in post harvest management of Chick Pea

\begin{tabular}{ccccc}
\hline & & \multicolumn{2}{c}{ No of respondents } & \multirow{2}{*}{ Total } \\
\cline { 3 - 4 } S1. No. & Problems & Yes & No & \\
\hline 1 & Labour availability & $42(70)$ & $18(30)$ & $60(100)$ \\
2 & Harvester availability & $39(65)$ & $21(35)$ & $60(100)$ \\
3 & Availability for transportation & $44(73.33)$ & $16(26.67)$ & $60(100)$ \\
4 & Scientific threshing yard & $34(56.67)$ & $26(43.33)$ & $60(100)$ \\
5 & Thresher available & $31(51.67)$ & $29(48.33)$ & $60(100)$ \\
6 & Winnower available & $29(48.33)$ & $31(51.67)$ & $60(100)$ \\
7 & Scientific storage & $37(61.67)$ & $23(38.33)$ & $60(100)$ \\
8 & Capital availability & $48(80)$ & $12(20)$ & $60(100)$ \\
\hline
\end{tabular}

Note: Figures in parentheses indicate percentage to total sample size $n=60$

Table 7: Farmer perceptions in Constraint to marketing of chick pea

\begin{tabular}{ccc}
\hline S1. No. & Constraints & Total \\
\hline 1 & Lack of cheap transportation & $57(95)$ \\
2 & Small marketable surplus & $55(91.67)$ \\
3 & Lack of regulated and co-operative market & $52(86.67)$ \\
4 & Lack of market intelligence & $48(80)$ \\
5 & Lack of storage management & $45(75)$ \\
\hline
\end{tabular}

Note: Figures in parentheses indicate percentage to total sample size $n=60$

important constraint reported by the growers was very small marketable surplus (91.67 per cent). Lack of regulated and co-operative market (86.67 per cent), followed by Lack of market intelligence (80 per cent) and lack of storage management (75 per cent) were the other prominent constraints reported by the pulse producers in study area.

\section{CONCLUSION AND SUGGESTION}

The overall post harvest loses at farm level was estimated to be $6.06 \mathrm{~kg} /$ quintal and $38.21 \mathrm{~kg} /$ hectare and maximum losses found during drying (36.93 $\%)$ followed by storage (35.61\%) and harvesting of chick pea $(09.81 \%)$ to the total losses. Total post harvest losses at farms level was found to be the maximum in large farms being $7.02 \mathrm{~kg}$. The marketable surplus in chick pea was 1.81, 2.62, 4.43, 18.27 and 4.17 quintal per farm constituting 67.79 , $70.37,73.46,77.87$ and 71.41 per cent to their total production. The overall quantity of chick pea sold by producer was $2.07(49.65 \%), 1.19(28.47 \%)$ and $0.91(21.88 \%)$ direct to consumer, village trader and wholesaler respectively. The major constraint in post harvest losses was unavailability of capital $(80 \%)$ and in marketing of chick pea lack of cheap transportation facility (95\%). There is a need to establishment of regulated market nearby to the study area, strengthen of the marketing channel and enhancement in productivity for the better marketable surplus, and also a need of extension activities for storage management and smoothening the process of financial agencies for farmer credit in the study area. And also it is suggested that the availability of cheap transportation facility were minimize the post harvest losses and advancement of the marketing channels in the study area.

\section{REFERENCES}

Anonymous report of World Bank, 2011.

Basavaraja, H., Mahajanashetti, S.B. and Udagatti, N.C. 2007. Economic analysis of post-harvest losses in food grain in India: a case study of Karnataka. Agricultural Economics Research Review, 20(1): 38-39.

Chatha, I.S. and Sidhu, D.S. 1984. Marketing of Kharif pulses in Punjab. Agricultural Marketing, 2(4): p17-21.

Grover, D.K. and Singh, J.M. 2013. Post-Harvest Losses in Wheat Crop in Punjab: Past and Present, Agricultural Research Review, 26(2). 
Nag, S.K., Nahatkar, S.B. and Sharma, O.H. 2000. Post-harvest losses of chickpea as perceived by the producers of Sehore district of Madhya Pradesh. Agricultural marketing (Oct.Dec.): 2000; 12-16.
Nirmal, V.K. 2008. Production and Marketing of major pulses in Rajnandgaon District of Chhattisgarh", M.Sc. (Agril. Eco.) IGAU-T-2146_2008, thesis Submitted to I.G.A.U. Raipur, C.G. 